Date of Publication: $26 /{ }^{*} 08 / 2013$

\section{Cunninghamia}

A journal of plant ecology for eastern Australia

ISSN 0727-9620 (print) • ISSN 2200 -405X (Online)

\title{
Replacement of Cakile edentula with Cakile maritima in New South Wales and on Lord Howe Island
}

\author{
Kevin Mills \\ 12 Hyam Place, Jamberoo, NSW 2533 Australia \\ k.mills@bigpond.net.au
}

\begin{abstract}
Two species of Cakile (Brassicaceae) have been introduced to Australia and the genus has been a common feature on the beaches of NSW for over 130 years; Cakile edentula has been present for at least 148 years (in NSW since about 1870), while Cakile maritima arrived approximately 114 years ago, (in NSW since about 1969). Collections at CANB and NSW confirm that since around 1970 plants more like Cakile maritima have almost entirely replaced Cakile edentula along the NSW coast. A similar phenomenon is reported for Lord Howe Island.
\end{abstract}

Cunninghamia (2013) 13: 291-294

doi: 10.7751cunninghamia.2013.006

\section{Introduction}

The genus Cakile (family Brassicaceae) contains seven species, all of which are naturally found only in the northern hemisphere. Two species have been introduced into Australia, Cakile edentula (American Sea Rocket) and Cakile maritima (European Sea Rocket). Cakile edentula var. edentula is the taxon found in Australia and is indigenous to the east coast of North America, where it grows on coastal shores, from northern Canada south to Florida. Cakile maritima subsp. maritima, the taxon found in Australia, is indigenous to Europe and northern Africa, and grows naturally throughout the Mediterranean and along the Atlantic coast. These herbaceous annuals are largely restricted to sandy beaches where they grow as sand-binding, strandline plants. The species grow in association with a suite of indigenous and several well-established introduced beach species. These species are termed 'drift-line pioneers' by Heyligers (1985) and in this regard Cakile is likened by that author to the natives Atriplex cinerea and Austrofestuca littoralis. Cakile is mostly found growing on coastal beaches, but sometimes occurs on the edges of saline coastal lakes with native saltmarsh species.

The spread of Cakile edentula and Cakile maritima along the NSW coast, and replacement of the former by the latter, has previously been documented (e.g. Heyligers 2007). A similar phenomenon on Lord Howe Island, a remote oceanic island $600 \mathrm{~km}$ east of NSW, has gone unreported until now. The mechanism behind this replacement has not been satisfactorily elucidated, although several hypotheses have been discussed in the past (e.g. Rodman 1986; Heyligers 2007). Cousens et al. (2013) reviewed the history of invasion of Cakile in Australia and found that Cakile maritima was introduced into Australia from morphologically distinct races. This explains the regional variation within Australia and the high variability in the appearance of this taxon in the southeast, without the need for introgression of Cakile edentula into Cakile maritima. 


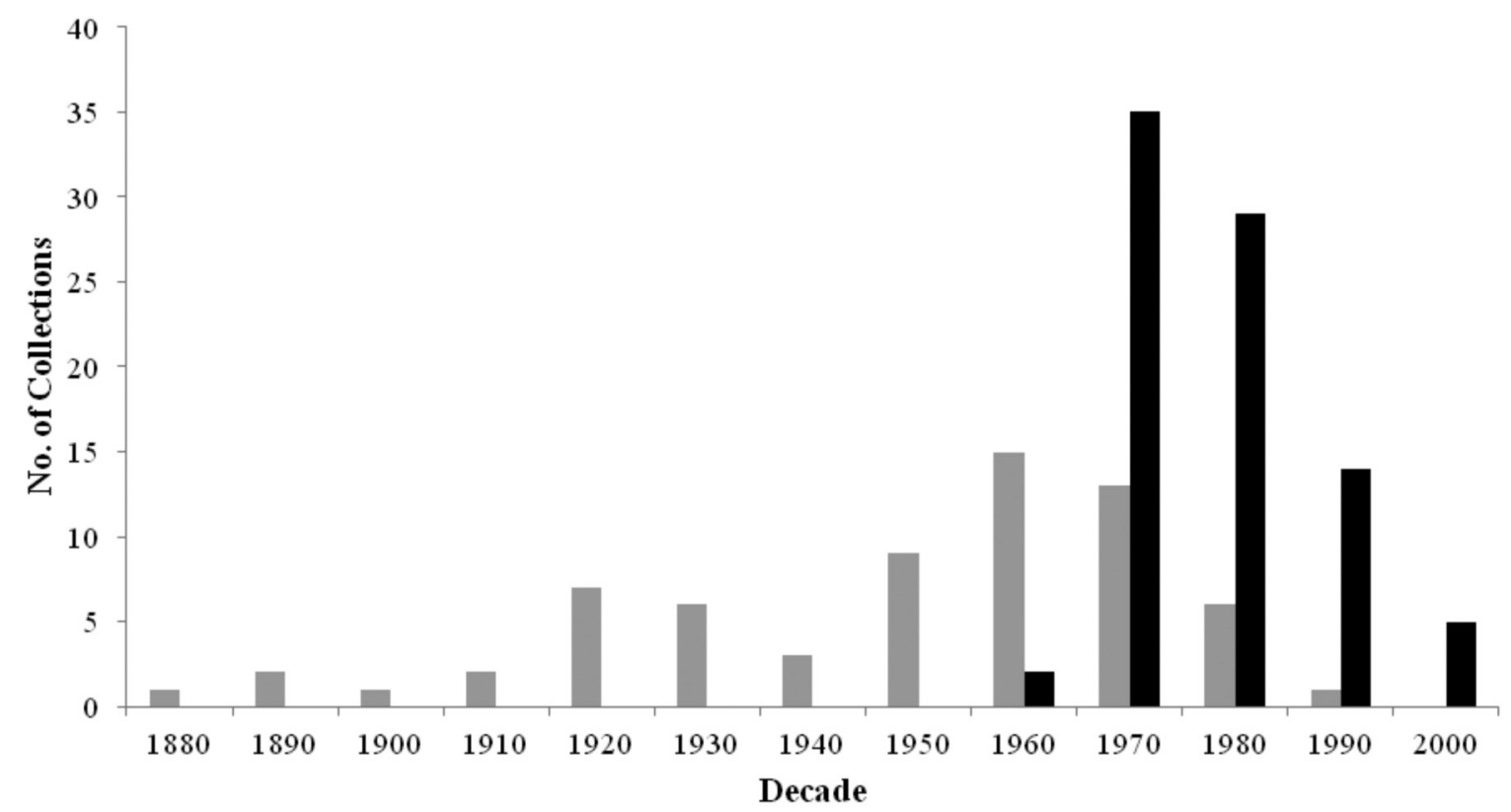

Fig. 1. Number of collections of Cakile from NSW at CANB and NSW, combined for each taxon in each decade. Grey - Cakile edentula; black - Cakile maritima.

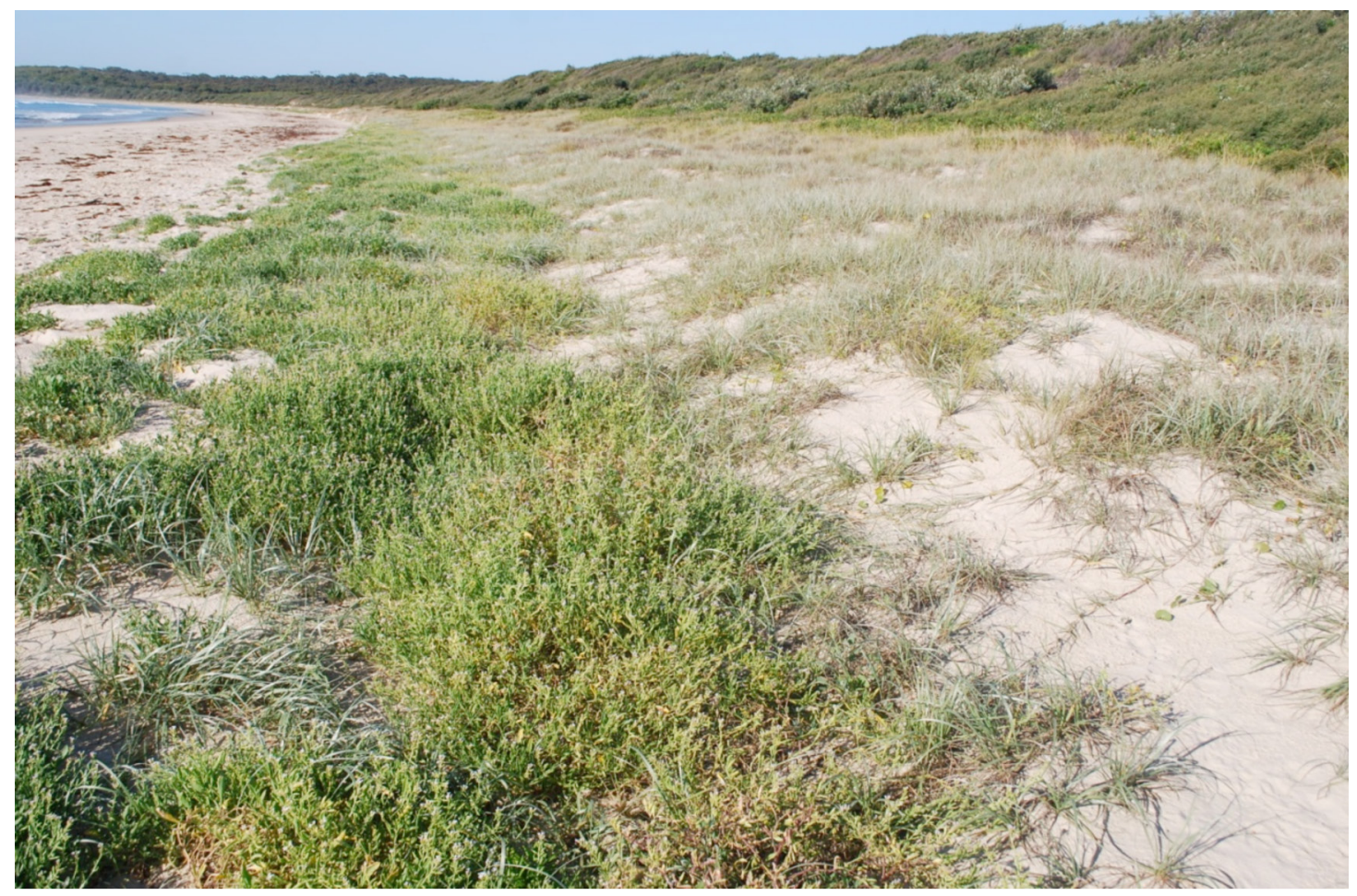

Fig. 2. A dense stand of Cakile maritima, to left, growing along the strandline on Berrara Beach, south coast of NSW. Date: 02 January 2012. 


\section{Cakile in the southwest Pacific}

Cakile edentula was first recorded in Australia at Phillip Island in Victoria in 1863, while Cakile maritima was first collected at Fremantle, Western Australia in 1897 (Heyligers 1985). The taxa are thought to have been brought to Australia in the ballast water of ships visiting from the northern hemisphere. The first collections and locations in NSW were respectively, Manly in 1870 (Cakile edentula) and Woy Woy in 1969 (Cakile maritima) (Heyligers 1989). Cakile edentula has been present in NSW for at least 142 years and by the 1920s had colonised the whole coast. Cakile maritima has been present in NSW for about 43 years. There was thus a 99 year gap between the first recorded observations of the two species in NSW; this compares with a 34 year gap between their earliest collections in Australia.

Extra-Australian occurrences of Cakile in the southwest Pacific are Lord Howe Island, the Kermadec Islands, New Zealand (North and South Islands) and Norfolk Island, the latter island with one record only, in 1902 (Maiden 1904), though Green (1994) noted that Maiden's 1902 specimen from Norfolk Island was actually Cakile edentula rather than Cakile maritima as suggested by Maiden. There have been no other records of Cakile from that island. At least some of these occurrences are likely to have been self introductions from Australia, rather than human assisted dispersals.

\section{Methods}

Lists of collections of both Cakile species in NSW and on Lord Howe Island were obtained from the National Herbarium of New South Wales in Sydney (NSW) and the Australian National Herbarium in Canberra (CANB). Those collections gathered from locations in NSW were identified and analysed according to their date of collection.

Table 1. Specimen collection dates of Cakile from Lord Howe Island (data from NSW and CANB herbaria)

\section{Cakile edentula}

Cakile maritima

Oct. 1898

Sept. 1908

August 1911

May 1920

27 Oct. 1963

16 July 1965

23 Sept. 1970

1 Sept. 1971

15 July 1978

23 Mar. 1979

Cakile maritima
-
-
-
-
-
-
-
-
-
-
17 July 2000
12 Nov. 2000
Nov. 2009 (observed, K.Mills)
Feb. 2010

Observations of Cakile on Lord Howe Island were made on a visit to that island in late 2009 .

\section{Results}

\section{Cakile on the NSW Coast}

Records of Cakile specimens along the NSW coast (lodged at NSW and CANB) were combined, based on species and decade of collection and demonstrate the demise of Cakile edentula and the expansion of Cakile maritima along the NSW coast (Figure 1). In the 1970s, Cakile edentula apparently began to disappear and plants identified as Cakile maritima began to be regularly collected. By about 2000 plants resembling Cakile edentula had all but disappeared from the collections and been replaced by plants more like Cakile maritima. This change has been documented in various papers by Heyligers (e.g. 1998).

\section{Cakile on Lord Howe Island}

On Lord Howe Island, $600 \mathrm{~km}$ east of the coast of NSW, both Cakile species have been recorded. The first record of the genus on the island was Cakile edentula in 1898 (NSW collection by E. King, October 1898) (Table 1), 28 years after it was first collected in NSW (Heyligers 1989). Rodd and Pickard (1983) list Cakile edentula as a "naturalized non-native species" for the island, although Pickard (1983) does not list is as a characteristic or common plant species in the beach communities that he describes.

Cakile edentula has also been replaced by Cakile maritima on Lord Howe Island, as evident from an analysis of herbarium collections and recent field observations (Table 1). Collections held at NSW indicate that Cakile edentula was collected on the island up to 1979; unfortunately, there are no specimens in either herbarium for 21 years after that year, though Green (1994) documented it for the island at that time. The first collections of Cakile maritima from Lord Howe Island are from 2000. Recent observations of Cakile on Lord Howe Island by the author are only of Cakile maritima (Mills 2009). As has occurred on the coast of New South Wales, Cakile edentula has disappeared on Lord Howe Island and been replaced by Cakile maritima.

\section{Conclusion}

The occurrence, abundance and distribution of introduced plants (exotics, weeds) is often highly dynamic, reflecting the unstable environments in which most weeds proliferate. Many of the species that are weeds in Australia are colonisers of disturbed ground in their region of origin, making them particularly successful introductions. In the case of Cakile in Australia, the species inhabit a naturally dynamic upper beach environment, as they do in their native countries.

Two species of Cakile have been present in Australia for well over 100 years. Cakile edentula had colonised the 
entire NSW coast by about 1920, while Cakile maritima was recorded along the whole coast by at least the 1970s. The "replacement" of the former by the latter taxon in southern Australia was noted by other workers (Rodman 1986; Cody \& Cody 2004; Heyligers 1998), the results obtained from field observations and herbaria records. The replacement of Cakile edentula by Cakile maritima along the NSW coast and on Lord Howe Island is consistent with observations on other coasts in southern Australia. Rodman (1986) noted a similar replacement of Cakile edentula with Cakile maritima on the Pacific coast of North America; interestingly, both species are introduced to that coast.

\section{Acknowledgements}

Data used in this work has come from the Australian National Herbarium Specimen Information Register (ANHSIR) database [extract at CANB, Excel file 2010] Australian National Herbarium (CANB) Canberra, and the database of specimens at the National Herbarium of New South Wales (NSW), Royal Botanic Gardens and Domain Trust Sydney. Doug Benson made useful comments on a draft of the paper.

\section{References}

Cody, M. L. and Cody, T. W. D. (2004). Morphology and special distribution of alien sea-rockets (Cakile spp.) on South Australian and Western Canadian beaches. Australian Journal of Botany 52: 175-183.

Cousens, R. D., Ades, P. K, Mesgaran, M. B. \& Ohadi, S. (2013). Reassessment of the invasion history of two species of Cakile (Brassicaceae) in Australia, Cunninghamia 13: xxx-xxx?

Green, P. (1994). Flora of Australia Volume 49. Oceanic Islands 1. Australian Government Publishing Service, Canberra, 681 pages.

Heyligers, P. (1985). The impact of introduced plants on foredune formation in south-eastern Australia. Proceedings Ecological Society Australia 14: 23-41.

Heyligers, P. (1989). Strandline Plants: History in the Making. Nature in Eurobodalla 3: 30-36.

Heyligers, P. (1998). Some New South Wales coastal plant distributions: a comparison of herbarium records with transect survey data. Cunninghamia 5(3): 645-664.

Heyligers, P. C. (2007). The role of currents in the dispersal of introduced seashore plants around Australia. Cunninghamia 10(2): 167-188.

Maiden, J.H. (1904). The Flora of Norfolk Island. Proceedings of the Linnean Society of New South Wales 28: 692-785.

Mills, K. (2009). The Beach and Estuarine Plants on Lord Howe Island. The author, unpublished.

Pickard, J. (1983). Vegetation of Lord Howe Island. Cunninghamia 1(2): 133-265.

Rodd, A. N. \& Pickard, J. (1983). Census of vascular plants of Lord Howe Island. Cunninghamia 1(2): 267-280.

Rodman, J. E. (1986). Introduction, establishment and replacement of sea-rockets (Cakile, Cruciferae) in Australia. Journal of Biogeography 13: 159-171.

Manuscript accepted 3 June 2013 